\title{
Subalpine-nival gradient of species richness for vascular plants, bryophytes and lichens in the Swiss Inner Alps
}

\author{
Pascal Vittoz • Martin Camenisch • Romain Mayor - Luca Miserere • \\ Mathias Vust $\cdot$ Jean-Paul Theurillat
}

Received: 3 March 2010/ Accepted: 31 August 2010/Published online: 6 October 2010

(C) Springer Basel AG 2010

\begin{abstract}
In the European GLORIA project, 12 summits (treeline to nival belt) were inventoried in three regions of Switzerland: two in the Swiss National Park Graubünden and one in Valais. Vascular plants were recorded in all three regions and bryophytes and lichens were recorded only in Valais. On each summit, vegetation and temperature data were sampled using sampling protocols for the GLORIA project (Global Observation Research Initiative in Alpine environment) on large summit sections and in clusters of four $1 \times 1$-m quadrats. We observed a general decrease of species richness for all three systematic groups with increasing elevation in the summit sections, but only for vascular plants in the quadrats. In Valais, there was higher species richness for vascular plants than for bryo-
\end{abstract}

Responsible editor: Sonja Wipf.

Electronic supplementary material The online version of this article (doi:10.1007/s00035-010-0079-8) contains supplementary material, which is available to authorized users.

P. Vittoz $(\square)$

Department of Ecology and Evolution,

Faculty of Biology and Medicine, University of Lausanne,

Bâtiment Biophore, 1015 Lausanne, Switzerland

e-mail: pascal.vittoz@unil.ch

P. Vittoz

Faculty of Geosciences and Environment,

University of Lausanne, 1015 Lausanne, Switzerland

M. Camenisch

Camenisch \& Zahner, Weinbergstrasse 6,

7000 Chur, Switzerland

R. Mayor

Institute of Plant Sciences, Bern University,

21 Altenbergrain, 3013 Bern, Switzerland phytes and lichens on the lower summits, but as the decrease in species richness was less pronounced for cryptogams, the latter were more numerous than vascular plants on the highest summit. Vascular species showed a clear shift of the dominant life form with elevation, with chamaephytes replacing hemicryptophytes. Bryophytes and lichens showed a weak trend among the life forms at the summit section scale, but a stronger shift of the dominant forms was seen in the quadrats, with cushion replacing turf bryophytes and crustaceous replacing fruticose lichens. Altogether, these results sustain the temperature-physiographic hypothesis to explain the species richness decrease along the altitudinal gradient: the harsh climatic conditions of the alpine-nival belts act as a filter for species, but the diminishing diversity of microhabitats is also an important factor. Because cryptogams depend more on humidity than temperature and more on smaller microhabitats than vascular plants, the decrease of species richness is more gradual with elevation for bryophytes and lichens.

\author{
L. Miserere \\ Via Melchiorre Voli 14, 10135 Turin, Italy \\ M. Vust \\ Rue Montolieu 5, 1030 Bussigny, Switzerland \\ J.-P. Theurillat \\ Fondation J.-M. Aubert, 1938 Champex-Lac, Switzerland \\ J.-P. Theurillat \\ Laboratory of Biogeography, Section of Biology, \\ University of Geneva, Case postale 60, \\ 1292 Chambésy, Switzerland
}


Keywords Altitude - Aspect - Diversity .

Elevation range $\cdot$ Life forms $\cdot$ Switzerland

\section{Gradient subalpin-nival de la richesse spécifique des plantes vasculaires, bryophytes et lichens dans les Alpes internes en Suisse}

Résumé Dans le cadre du projet européen GLORIA, 12 sommets (de la limite de la forêt à l'étage nival) ont été inventoriés dans trois régions de Suisse: deux dans le Parc national suisse (Grisons) et une en Valais. Les plantes vasculaires ont été étudiées dans les trois régions alors que les bryophytes et lichens n'ont été considérés qu'en Valais. Le protocole du projet GLORIA (Global Observation Research Initiative in Alpine environment) a été utilisé sur tous les sommets, avec des inventaires sur de grandes sections sommitales et sur des groupes de quatre carrés de $1 \times 1 \mathrm{~m}$. Nous avons observé une diminution générale de la richesse spécifique dans les trois groupes systématiques pour une altitude croissante dans les sections, mais pour les plantes vasculaires seules dans les carrés. En Valais, il y avait davantage de plantes vasculaires que de lichens et de bryophytes sur les sommets inférieurs mais, comme la diminution de la richesse spécifique était moins marquée pour les cryptogames, ces derniers étaient plus nombreux que les plantes vasculaires sur le sommet le plus élevé. Pour les plantes vasculaires, nous avons observé un changement net des formes de croissances dominantes, avec le remplacement des hémicryptophytes par les chaméphytes lorsque l'altitude augmente. Les bryophytes et les lichens ont montré qu'un faible changement des formes de croissance dominantes dans les sections sommitales mais un changement plus net au niveau des carrés: les coussinets remplacent en proportion la forme gazonnante des bryophytes et les lichens crustacés remplacent les lichens fruticuleux. Dans l'ensemble, ces résultats correspondent bien à l'hypothèse "température-physiographie" pour expliquer la diminution de la richesse spécifique le long du gradient altitudinal: les conditions climatiques rudes des étages alpin et nival agissent comme un filtre pour les espèces, mais la diminution des micro-habitats est également un facteur important. Comme les cryptogames dépendent plus de l'humidité que de la température et qu'ils se contentent de micro-habitats plus restreints que les plantes vasculaires, la richesse spécifique des bryophytes et des lichens diminue moins vite avec l'altitude.

\section{Introduction}

It is generally accepted that, in terrestrial environments, species richness decreases with altitude as with latitude (e.g.
Rahbek 1995; Theurillat et al. 2003; Stanisci et al. 2005; Grytnes et al. 2006; Theurillat et al. 2010). Different studies have shown that, when the complete gradient is considered, the species-richness curve is hump-shaped with elevation with a maximum in the lower half of the gradient, but it shows a monotonic decrease with latitude (Rahbek 1995; Rahbek 2005). The assessment of the altitudinal gradient is, however, complicated by the numerous intercorrelated environmental gradients: atmospheric pressure, temperature, rainfall, solar radiation, wind, season length, variation of steepness, geomorphological perturbations, reduction of surface size and human land use (Körner 2007; Rahbek 2005).

Many mechanisms that are not mutually exclusive were suggested to explain the species-richness decrease with elevation, and a number of them are related to the ecological gradients associated with elevation. Available energy was often proposed as a determining mechanism, as more usable energy should allow for a higher number of distinct plant niches (Whittaker 1999). The mass effect (or source-sink dynamics) may explain the mid-altitudinal peak frequently observed (e.g. Grytnes 2003; Nogues-Bravo et al. 2008; Rahbek 2005). Because species distribution is limited on an elevation gradient by abrupt boundaries (i.e. ocean, valley bottom, mountain summits), species whose distribution is restricted by these boundaries can disperse in only one direction, and conversely these regions receive seeds from only one direction. Hence, the highest richness in the middle of the gradient results from more sink populations (Bhattarai and Vetaas 2006; Grytnes 2003; Grytnes et al. 2008). Rapoport's rule extended to the elevation gradient (Stevens 1992) suggests that, because of the high climatic variability, species have a broader environmental tolerance at higher elevations (e.g. Gaston 2000), which leaves fewer available niches. However, Vetaas and Grytnes (2002) and Bhattarai and Vetaas (2006) observed an opposite distribution of the amplitude of elevation ranges. Some of the other suggested mechanisms explain the current species distribution on the basis of historical factors (Gaston 2000). Körner (2000) suggested that the short growth season in the alpine or arctic environment strongly reduces the available time for evolution to occur. Similarly, Rohde et al. (1993) observed that the speciation rate is higher in warmer climates because of the effect of temperature on mutation rate. Moreover, the size of the homogeneous region is a major determinant of the number of species (Huston 1999), and mountains have a diminishing size with increasing elevation due to their conic shape (Körner 2000; Theurillat and Guisan 2001; Bhattarai and Vetaas 2006). Finally, Theurillat et al. (2003) merged different models in their temperature-physiography hypothesis. At the biological level (biological filter), increasingly cold temperatures with higher elevations select the species with better cold adaption, determining the pool 
of the potential species able to withstand the increasingly severe conditions in the alpine belt (Körner 2003). At the geomorphological level of nano- and microrelief (respectively, $1-100 \mathrm{~cm}, 1-100 \mathrm{~m}$ ), colder temperatures reduce fluvial processes because of longer winters. In contrast, periglacial processes increase with colder temperatures. Additionally, slopes get steeper with elevation in young mountains like the Alps, which increases gravitational processes (Theurillat and Guisan 2001). All of these processes result in an increasing geomorphological convergence, thus reducing habitat diversity (environmental filter). In addition, at the community level, colder temperatures reduce productivity, consequently reducing human land use, which is a source of secondary habitats. As was underlined by Lundholm (2009), spatial heterogeneity and habitat diversity are important determinants of species richness at the local scale. Therefore, colder temperatures determine a decrease in species richness by acting as both a biological and an environmental filter (see Appendix 1 in supplementary online material).

In 2001, the GLORIA project (Global Observation Research Initiative in Alpine Environments; http://www. gloria.ac.at) established a long-term observation network in alpine environments to monitor climate change impact on alpine vegetation. On the basis of a standardised protocol, plant species composition has been investigated on groups of four summits scattered between the treeline and the nival belt in different regions in Europe, and, more recently, the study has been extended to the rest of the world. Three of these regions are in the Swiss Alps, two in Graubünden (East Switzerland) and one in Valais (South-West Switzerland). Results from the GLORIA inventories offer an interesting opportunity to investigate plant species-richness patterns along the subalpine-nival elevation gradient, especially because bryophytes and lichens were also inventoried in the Valais site. The following hypotheses were assessed: if temperature is an important component of the species richness gradient, (1) species richness ought to decrease with increasing altitude, and (2) different aspects ought to contain different number of species, as previously observed (e.g. Braun 1913; Coldea and Pop 2004; Stanisci et al. 2005); (3) on the basis of the temperature-physiography hypothesis (Theurillat et al. 2003), cryptogams, which depend on smaller microhabitats than vascular plants, ought to show a different pattern than vascular plants along the altitudinal gradient (Virtanen and Crawley 2010); (4) following Vetaas and Grytnes (2002) and Bhattarai and Vetaas (2006), Rapoport's rule is not verified with an altitudinal gradient; and (5) because the ability of vascular plants and cryptogams to modify their temperature depends on their life form (Körner 2003; Glime 2007), life form spectra change in relation to the elevation gradient.

\section{Methods}

Sites and field inventories

Three regions were established in Switzerland for the GLORIA project (Appendix 2): two in the Swiss National Park (abbreviated SNs and SNc) in Graubünden, in the east of the country, and one in Valais (VALs) in western Switzerland. SNs and VALs lay on siliceous rock, whereas SNc is on calcareous rock. Each region contained four summits scattered between the upper treeline $(2,360-2,438$ m.a.s.l.) and the nival belt (3,092-3,212 $\mathrm{m}$ a.s.1.).

Inventories followed the GLORIA protocol (Pauli et al. 2004). Summits were divided into four sectors following cardinal directions. Each sector was further subdivided into $0-5$ - and 5-10-m zones below the highest point, resulting in eight summit area sections (hereafter, summit sections). Within each summit section, botanical recording was carried out to list all species present. In each 5-m section, a $3 \times 3-\mathrm{m}$ cluster was set at the lower boundary, in which the four corners were used as $1 \times 1-\mathrm{m}$ quadrats. These quadrats were recorded by listing all species present. Vascular plants were inventoried in all regions, and bryophytes (all systematic and ecological groups) and terricolous lichens were also recorded in the VALs region. The regions SNs and SNc were inventoried in August 2002 (August 2003 for Munt Buffalora and Mot sper Chamana Sesvenna) and VALs was inventoried in July-August 2008. In this last region, three clusters (Pte du Parc, west and south aspects; Pte de Boveire, west aspect) were not inventoried because the substrates were too steep and unstable.

Soil temperature was measured hourly with StowAway Tidbit $T$ dataloggers (Onset, Bourne, MA, USA) buried $10 \mathrm{~cm}$ in the soil during 3 years (SNs and SNc, 2002-2005) or 6 years (VALs, 2001-2008). On each summit of the VALs region, four loggers were set (one for each aspect) in the middle of the $3 \times 3$-m cluster. On each summit of the $\mathrm{SNc}$ and SNs regions, only one logger was set at the highest summit point.

\section{Analyses}

Because the two summit sections of a same aspect cannot be considered as independent inventories (pseudoreplication) for subsequent analyses, we used the total number of species observed in both sections merged together. Similarly, the total number of species observed in each cluster of four $1 \times 1$-m quadrats was used for analyses. However, on many summits, especially the highest ones, the very irregular microtopography resulted in very different compositions for the four quadrats of the same cluster, which would justify individual treatment of the quadrats (unpublished analyses 
showed that both treatments gave largely similar results). The areas and the mean slopes of summit sections were estimated by trigonometry on the basis of angles and lengths measured in the field. The same slope values were used for the clusters.

Daily mean temperature was calculated from the hourly measures. The start of the growing season was defined as the first day with a mean temperature $>2^{\circ} \mathrm{C}$ as long as this temperature was maintained for at least 4 days. Similarly, the end of the growing season was defined as the first day with a mean temperature $<2^{\circ} \mathrm{C}$ as long as this temperature was maintained for at least 4 days. Mean winter temperature was calculated as the mean of the December-February period. However, because of the differences in the location of the dataloggers between regions, we could not further use these values in the comparative analyses. They are, however, presented in Appendix 2.

Because the summit sections have different areas, we carried out comparisons of species richness by using the residuals of a linear regression between species richness and section area or we compared the proportion of species in different categories (life forms or elevation range, see below). Otherwise, the recorded number of species was used directly for comparisons of richness between clusters of quadrats. These clusters have a constant size but are not representative of the section diversity (clusters are at a fixed position and much smaller than summit sections).

The species were classified into life forms (Raunkiaer 1934) following Aeschimann et al. (2004) for vascular plants (therophyte, geophyte, chamaephyte, hemicryptophyte, phanerophyte), Nimis and Martellos (2008) for lichens (fruticose, foliaceous, squamulous, crustaceous) and Glime (2007) for bryophytes (mat, turf, weft, cushion). Similarly, species were classified for their elevation range into four altitudinal classes: (1) species with a large elevation range from colline $(<800 \mathrm{~m})$ or montane (800-1,500 m) belts to the treeline $(2,300 \mathrm{~m})$; (2) species with a large elevation range from colline or montane belts to the alpine belt $(2,300-3,000 \mathrm{~m})$; (3) species in subalpinealpine belts $(1,500-3,000 \mathrm{~m})$; (4) species in alpine-nival belts $(>2,300 \mathrm{~m})$. This classification was carried out following Aeschimann et al. (2004) for vascular plants, Clerc (2004) for lichens and Nyholm (1986-1998), Paton (1999), Cortini Pedrotti (2001), Smith (2004), Cortini Pedrotti (2006), and Schumacker and Váňa (2005) for bryophytes.

For analysing the altitudinal trend, we used linear mixed models (LMMs) fitted by the restricted maximum likelihood method (REML; Bates and Maechler 2009). The $P$ values were obtained by using 10,000 random permutations with Markov chains. We used REML because it is adapted to unbalanced datasets (Faraway 2006) and to the specification of random factors. In all of the mixed models, we used the factor "summit" as a random factor to control for pseudoreplication due to repetition of samplings on the same summit (McKone 1993). Analyses were carried out for vascular plants on the twelve available summits (three regions) by incorporating altitude, region, aspect and slope as explanatory fixed factors. We added the aspect $\times$ altitude interaction because the different aspects are susceptible to showing different gradients of species richness with elevation. Comparisons between the three systematic groups were carried out on the four summits of the VALs region by incorporating altitude, slope and systematic group as explanatory fixed factors. Aspect was not considered here because of the low number of replicates (four summits). We added the systematic group $\mathrm{x}$ altitude interaction because systematic groups may show different gradients with elevation. Preliminary trials showed that interactions with slope were never significant. In the LMM results, the number of observations (number of samples considered in the analysis) and the number of groups (number of summits included, as they were used as random factors) were indicated.

To illustrate the gradients and the variation along them, we complemented previous analyses with linear regressions. All analyses were performed in R (R Development Core Team 2009).

\section{Results}

An overview of the summits, their characteristics, the mean temperatures and the number of species recorded on the whole summits and by aspects is given in Appendix 2 .

The species richness of vascular plants decreased with increasing altitude in all analyses. This trend was highly significant in summit sections (Table 1) and in clusters of four $1 \times 1-\mathrm{m}$ quadrats (Table 2) for the three regions (Appendix 3). Species richness was never directly influenced by slope. The SNc region was more species-rich in vascular plants than VALs, which was richer than SNs (Tables 1,2) at the two investigated scales. This difference was similarly recorded when the whole summits were considered, at least for the lowest altitudes (Appendix 3).

LMMs showed no significant influence of aspect on species richness of vascular plants in the summit sections (Tables 1, 2). However, graphics showed that the east and south aspects were regularly richer than the north and west aspects for the lower summits (Appendix 3).

In the VALs region, vascular plants, bryophytes and lichens together showed a decreasing species richness with increasing altitude in summit sections and quadrats (Table 3; Appendix 4), but vascular plants were more species-rich than bryophytes and lichens, and the three systematic groups showed different trends along the altitudinal gradient (significant interaction of systematic group $x$ altitude; Table 3; Appendix 4). When the systematic groups 
Table 1 Results of a linear mixed model for the species richness of vascular plants in the summit sections of the three regions in relation to the altitude, aspect, slope and region

\begin{tabular}{lrrrr}
\hline & Estimate & Std. Error & $t$ value & $P$ value \\
\hline Intercept & 155.335 & 43.142 & 3.601 & $<0.001$ \\
Altitude & -0.059 & 0.016 & -3.766 & $<\mathbf{0 . 0 0 1}$ \\
Aspect north & -31.429 & 38.147 & -0.824 & 0.480 \\
Aspect south & 69.609 & 38.141 & 1.825 & 0.138 \\
Aspect west & -41.686 & 38.483 & -1.083 & 0.460 \\
Slope & -0.204 & 0.200 & -1.022 & 0.871 \\
Region SNc & 27.232 & 9.253 & 2.943 & $<\mathbf{0 . 0 0 1}$ \\
Region VALs & 28.005 & 9.623 & 2.910 & $\mathbf{0 . 0 0 2}$ \\
Altitude:aspect north & 0.007 & 0.014 & 0.516 & 0.633 \\
Altitude:aspect south & -0.025 & 0.014 & -1.814 & 0.149 \\
Altitude:aspect west & 0.011 & 0.014 & 0.797 & 0.632 \\
\hline
\end{tabular}

To eliminate the differences of areas between summit sections, the analyses were run on the residuals of a linear regression of species richness versus section area. The east aspect and the SNs region were used as references. Analysis was carried out with 48 observations and 12 groups. Bold values indicate $P<0.05$

Table 2 Results of a linear mixed model for the species richness of vascular plants in quadrats of the three regions in relation to the altitude, aspect, slope and region

\begin{tabular}{lrrrr}
\hline & Estimate & Std. error & $t$ value & $P$ value \\
\hline Intercept & 132.841 & 20.814 & 6.382 & $<0.001$ \\
Altitude & -0.043 & 0.007 & -5.807 & $<\mathbf{0 . 0 0 1}$ \\
Aspect north & -38.944 & 21.187 & -1.838 & 0.116 \\
Aspect south & -22.306 & 21.511 & -1.037 & 0.411 \\
Aspect west & -53.818 & 23.795 & -2.262 & 0.072 \\
Slope & 0.012 & 0.083 & 0.141 & 0.935 \\
Region SNc & 13.403 & 4.140 & 3.238 & $<\mathbf{0 . 0 0 1}$ \\
Region VALs & 7.509 & 4.248 & 1.768 & $\mathbf{0 . 0 4 0}$ \\
Altitude:aspect north & 0.011 & 0.008 & 1.448 & 0.212 \\
Altitude:aspect south & 0.007 & 0.008 & 0.924 & 0.477 \\
Altitude:aspect west & 0.016 & 0.009 & 1.863 & 0.140 \\
\hline
\end{tabular}

The east aspect and the SNs region were used as references. Analysis was carried out with 45 observations (the south and west aspect of Pte $\mathrm{du}$ Parc and the west aspect of Pte de Boveire were not sampled) and 12 groups. Bold values indicate $P<0.05$

were considered individually, we observed different trends in summit sections and quadrats. In summit sections, all three systematic groups showed significantly decreasing species richness with increasing altitude (linear regression) but with a steeper slope for vascular plants (Appendix 3). In quadrats, only the richness of vascular plants was significantly related to altitude, whereas bryophytes and lichens showed no significant trends (Fig. 1).

The analyses of the distribution of species elevation ranges were based on species proportions in the summit
Table 3 Results of a linear mixed model for the species richness in the summit sections of the VALs region in relation to the altitude, systematic groups and slope

\begin{tabular}{lrrrr}
\hline & Estimate & Std. error & $t$ value & $P$ value \\
\hline Intercept & 169.900 & 33.870 & 5.017 & 0.005 \\
Altitude & -0.059 & 0.012 & -4.919 & $\mathbf{0 . 0 0 6}$ \\
Bryophytes & -104.400 & 37.500 & -2.785 & $\mathbf{0 . 0 0 9}$ \\
Lichens & -108.800 & 37.500 & -2.901 & $\mathbf{0 . 0 0 5}$ \\
Slope & -0.004 & 0.148 & -0.030 & 0.964 \\
Altitude:bryophytes & 0.034 & 0.013 & 2.558 & $\mathbf{0 . 0 1 6}$ \\
Altitude:lichens & 0.038 & 0.013 & 2.799 & $\mathbf{0 . 0 0 7}$ \\
\hline
\end{tabular}

To eliminate the differences of areas between the summit sections, the analyses were run on the residuals of a linear regression of species richness versus section area. The vascular plants were used as reference. Analysis was carried out with 48 observations and 4 groups. Bold values indicate $P<0.05$

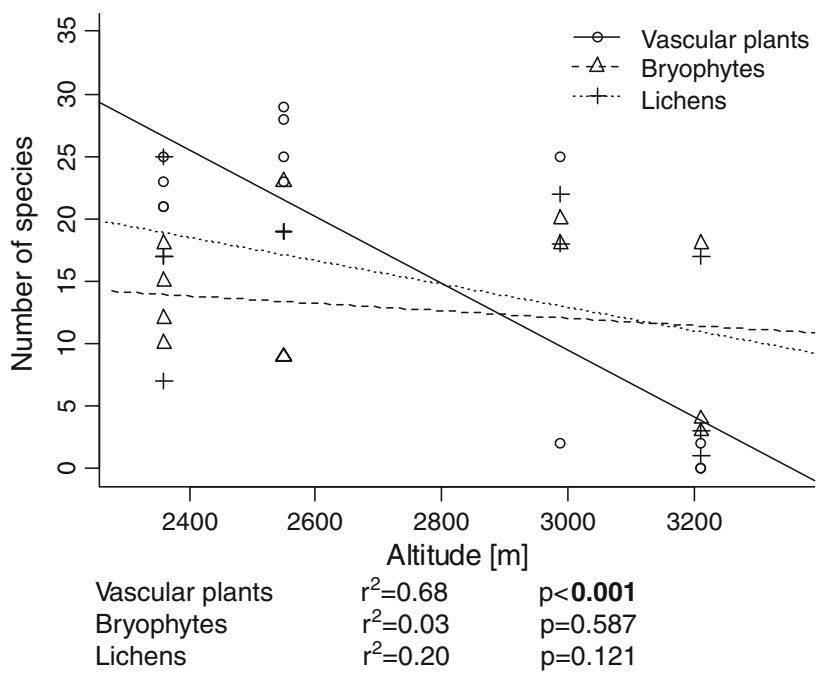

Fig. 1 Number of species in quadrats in relation to the altitude in the VALs region

sections (proportions are not influenced by the differences of areas). In the three regions, vascular plants with a large elevation range (colline or montane to treeline or alpine belts) decreased with increasing altitude, whereas species restricted to alpine-nival belts proportionally increased (Fig. 2). Subalpine-alpine species dominated the flora up to 2,700-2,800 m, but alpine-nival species dominated above this threshold.

In the VALs region, bryophytes and lichens showed less difference in their distributions, with significant trends only for bryophytes and for the extreme categories of lichens (Fig. 3). Species considered to having a large elevation range were still abundant on the highest summits, even dominating among the bryophytes, and only a few bryophytes were considered as strictly alpine-nival species. 


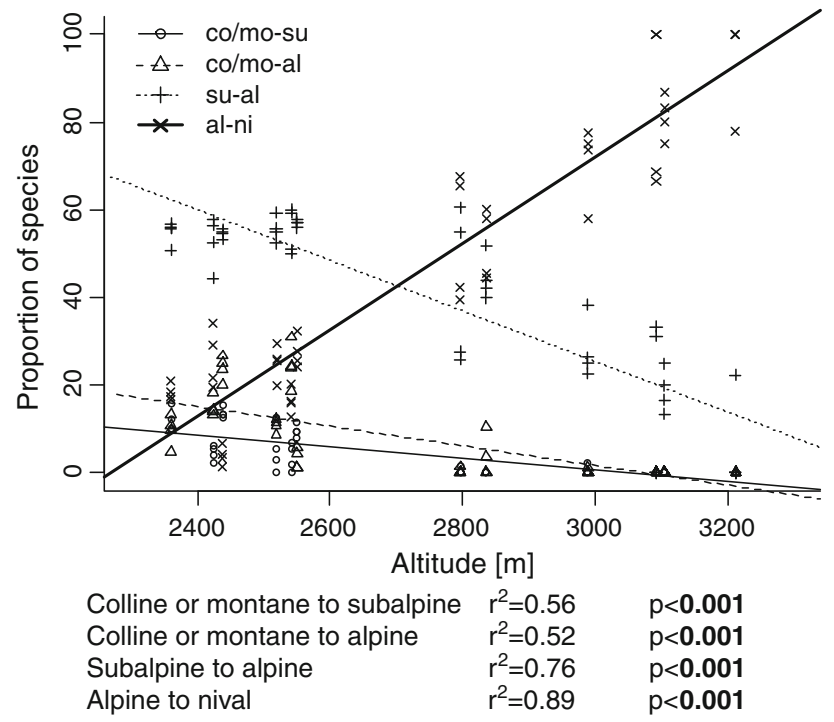

Fig. 2 Altitudinal classes for the elevation range of the vascular plant species recorded in the summit sections of the three regions in relationship to the altitude. Vegetation belts are abbreviated to the two-first letters

When the summit sections of the three regions were considered, hemicryptophytes and chamaephytes largely dominated all of the sections (phanerophytes, therophytes and geophytes never exceeded $15 \%$ and were present mostly on the lowest summits; Appendix 5). An LMM showed an increasing proportion of chamaephytes compared to hemicryptophytes with increasing altitude (Table 4). However, the number of species in both groups decreased along the elevation gradient, but hemicryptophytes exhibited a steeper decrease (not shown). The SNc region showed proportionally more hemicryptophytes than the other regions, and the north aspect had a lower proportion of hemicryptophytes than the east aspect (Table 4).

In the VALs region, bryophytes were dominated everywhere by the turf species in the summit sections. Among the other life forms, we observed an exchange along the altitudinal gradient, with the cushion bryophytes proportionally replacing the mat life form (Fig. 4). However, in absolute numbers, the cushion life form was stable, whereas the mat life form was characterised by a strong decrease (not shown). The proportions of the different lichen life forms were even more stable, with only a significant decrease of foliaceous lichens. However, the results were much different when the quadrats were considered, with a clear shift in species proportions from turf to cushion bryophytes and from fruticose to crustaceous lichens with increasing altitude (Appendix 6).

\section{Discussion}

Species richness of vascular plants along the altitudinal gradient

As expected, the species richness of vascular plants decreased with increasing altitude. This trend was observed in summit sections and in clusters of four $1 \times 1$-m quadrats (Table 1; Appendix 3). Because the differences of the areas between summits sections were previously eliminated by using the residuals of a linear regression between species richness and section areas in the analyses, we can be confident of both trends. A similar decrease was previously
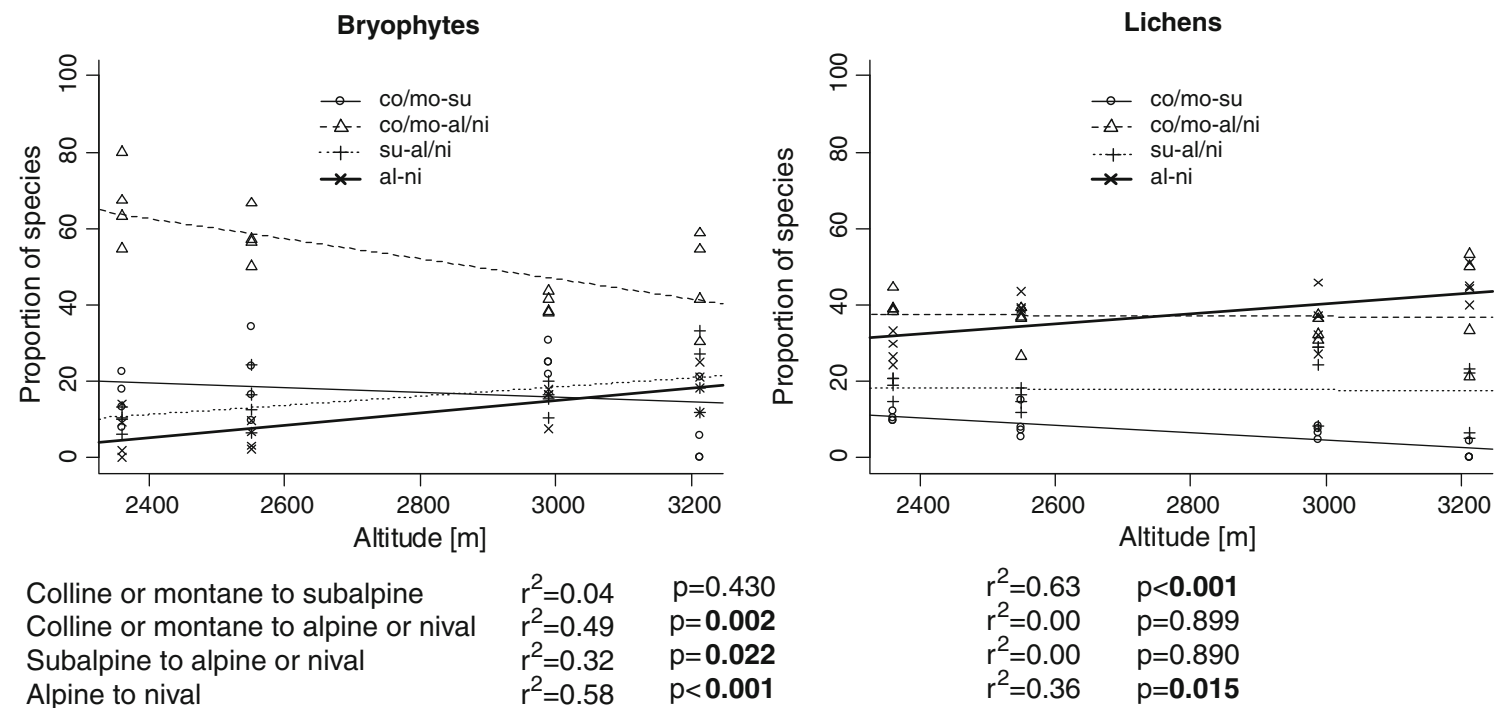

Fig. 3 Altitudinal classes for the elevation range of bryophytes and lichens recorded in the summit sections of the VALs region in relation to the altitude. Vegetation belts are abbreviated to the two-first letters 
Table 4 Result of a linear mixed model for the life forms of vascular plants (ratio of the number of hemicryptophytes/number of chamaephytes) in summit sections of the three regions in relation to the altitude, aspect and region

\begin{tabular}{lrlrl}
\hline & Estimate & Std. error & $t$ value & $P$ value \\
\hline Intercept & 9.546 & 1.738 & 5.494 & 0.000 \\
Altitude & -0.003 & 0.001 & -4.583 & $\mathbf{0 . 0 0 0}$ \\
Aspect north & -0.660 & 0.261 & -2.523 & $\mathbf{0 . 0 2 9}$ \\
Aspect south & 0.041 & 0.261 & 0.159 & 0.889 \\
Aspect west & -0.489 & 0.261 & -1.872 & 0.100 \\
Region SNc & 1.199 & 0.442 & 2.712 & $\mathbf{0 . 0 0 2}$ \\
Region VALs & 0.030 & 0.443 & 0.067 & 0.933 \\
\hline
\end{tabular}

The east aspect and the SNs region were used as references. Analysis was carried out with 48 observations and 12 groups. Bold values indicate $P<0.05$

recorded several times in the Alps (Theurillat et al. 2003; Erschbamer et al. 2006), in the Apennines (Stanisci et al. 2005; Theurillat et al. 2010) and in Scandinavia (Bruun et al. 2006).

Differences between aspects for vascular plants

Contrary to our expectations and previous observations, LMMs did not show any significant differences of species richness between aspects (Tables 1, 2). Indeed, north-south differences have been observed since long (e.g. Braun 1913), and in two other GLORIA regions, the Carpathians (Coldea and Pop 2004) and the Apennines (Stanisci et al. 2005), it was found that the east aspect was richer than the other aspects. Additionally, an increasing altitudinal limit of alpine grassland from the south-western to the south-eastern slopes was observed in the central Eastern Alps (Gottfried et al. 1998). Stanisci et al. (2005) related this trend to the slightly warmer soils on the east aspect than on the south one.

The absence of difference between aspects in the Swiss regions detected by LMMs might be a methodological limit; the quadrats on the west aspect were slightly poorer than on the east aspect (marginally significant in Table 2). In addition, an LMM applied to the $1 \times 1-\mathrm{m}$ quadrats individually indicated a richer east aspect than the other aspects (not shown), and graphics showed that the east and south aspects were richer in species than the north and west aspects in the summit sections and quadrats (Appendix 3). This variation in species richness corresponded to warmer mean temperatures during the growing seasons on the east and south aspects compared to the north and west aspects in the VALs region (Appendix 2). These differences between aspects are probably due to different factors. Soils in all areas are cold at sunrise, but the sun warms the east first, followed by the south and, only later in the day, the west aspect. In the afternoon, although the east aspect receives less radiation than the west one, the high air temperature is enough to maintain efficient physiological conditions in the east on sunny days. Also, a greater ground warming on the other aspects in the afternoon does not occur when condensation clouds form over mountain summits with diurnal heating (Barry 1992). In addition, evaporative cooling by wind (Barry 1992; Körner 2003) is stronger on the north-western summit slopes that are predominantly windward oriented. Hence, although the amount of energy received is a priori similar in the west and east aspects, better plant growth would result in the east.
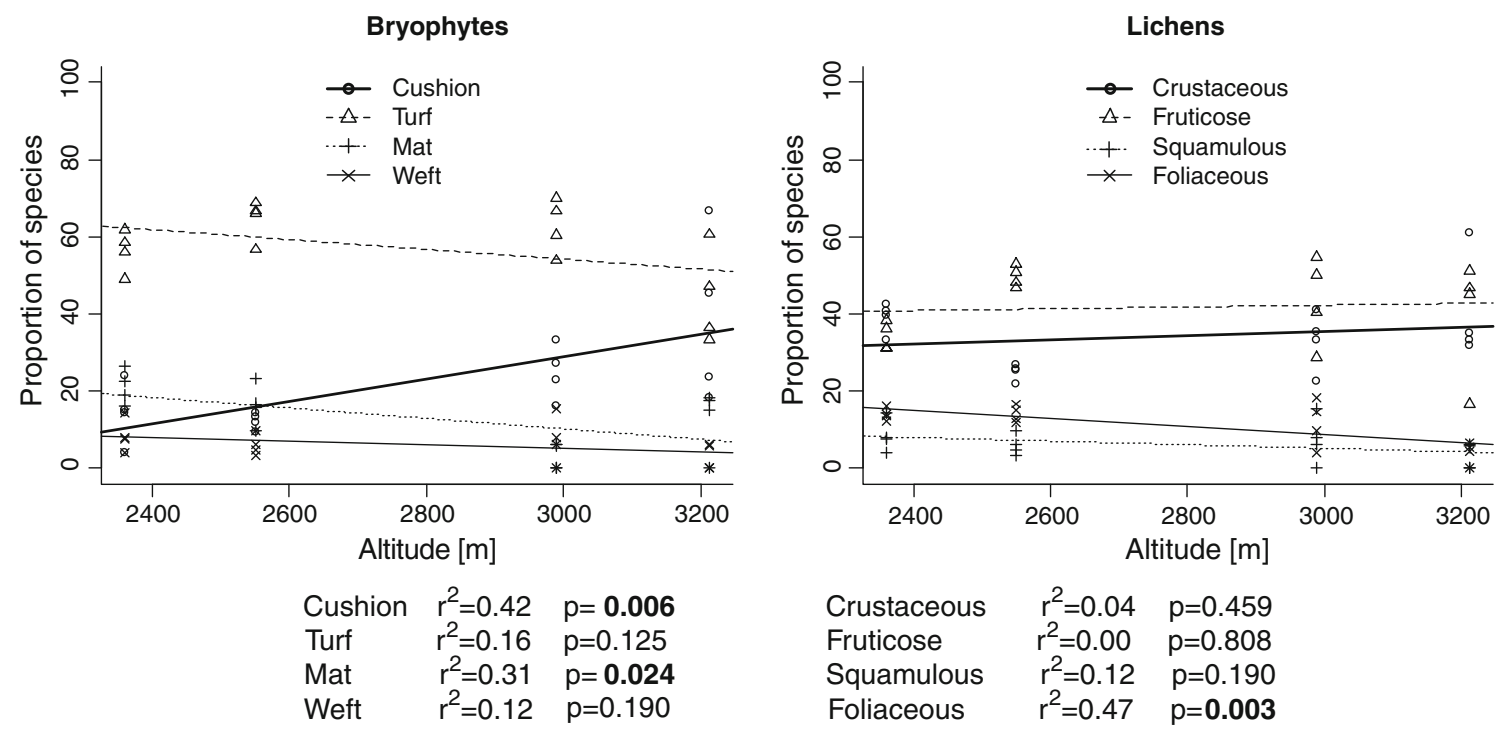

Fig. 4 Life forms of bryophytes and lichens recorded in the summit sections of the VALs region in relation to altitude 
Species richness of cryptogams

In the VALs region, bryophytes and lichens showed a less distinct pattern than vascular plants; species richness decreased less markedly than vascular plants at the summit section scale (Appendix 3), and there was no significant trend for bryophytes and lichens in the quadrats (Fig. 1). Examples for the distribution of cryptogam species richness above the treeline are rare in the literature. However, our results are in line with previous observations for bryophytes by Theurillat et al. (2003) in the Alps and Bruun et al. (2006) in Scandinavia, both of whom showed a weaker trend for bryophytes than for vascular plants with altitude, or even no trend at all. One of the consequences of these different trends with altitude was a shift of species richness between vascular plants and cryptogams above $\sim 3,000 \mathrm{~m}$ : vascular plants were more numerous than bryophytes and lichens on the lower summits but less numerous on the highest summit.

\section{Distribution of species' elevation range}

Our results showed a clear distribution trend of the elevation ranges for vascular plants (Fig. 2): species with a large elevation range (colline to subalpine or alpine) decreased with increasing altitude, whereas species with a narrow elevation range (strictly alpine-nival) increased in proportion along the same gradient. The same trend was recorded by Theurillat et al. (2003) in three longer transects $(1,800-2,800 \mathrm{~m})$ in Valais, with a shift of the dominance around 2,500 m. Similarly, Bhattarai and Vetaas (2006) observed a decrease of the mean elevation range in the Himalayas above $1,500 \mathrm{~m}$. These authors, similar to Grau et al. (2007) for bryophytes, concluded that Rapoport's rule (Stevens 1992), which states that species have a broader environmental tolerance at higher altitudes, could not be verified with altitudinal gradients in the mountains. Indeed, species with narrow elevation ranges, which were mainly those restricted to the alpine-nival belts, largely dominated the highest summits in Switzerland.

A similar increase in the proportions of species with a narrow elevation range (alpine-nival) was observed for bryophytes and lichens but with a strongly reduced intensity and a dominance of species with large elevation ranges along the whole gradient for both systematic groups (Fig. 3). This finding shows that cryptogams generally have much broader elevation ranges than vascular plants, what was recently confirmed for bryophytes in the Swiss Biodiversity Monitoring (Bureau de coordination du Monitoring de la Biodiversité en Suisse 2009). This result is in line with Glime's synthesis (2007), which showed that bryophytes generally have broader possible temperature ranges than vascular plants, with many species still able to photosynthesise at $-15^{\circ} \mathrm{C}$, and that some tropical mosses are even able to tolerate temperatures below $-10^{\circ} \mathrm{C}$. The thin structure of these species allows a rapid desiccation of the cells (poikilohydric organisms), which is associated with frost protection (increased solute concentration in the cells, which permits supercooling of intracellular water) while vascular plants have a cuticle to avoid water loss. Few data are available for lichens regarding similar adaptations, but they share many characteristics with bryophytes (dessication, thin structure, etc.), and Lange (2003) observed net photosynthesis of lichens under snow with a temperature of $-4^{\circ} \mathrm{C}$. Globally, the growth of bryophytes and lichens is more limited by water availability than by temperature (Lange 2003; Glime 2007), and water is not a limiting factor in the Swiss alpine belt because it is available almost every day, at least in the form of dew in the morning.

Another way to interpret the weak trends observed for cryptogams, and especially for lichens, is to question their classification into categories of elevation ranges. This classification was created in the most recent and complete book about lichen distribution in Switzerland (Clerc 2004), but alpine lichens have been little documented. Therefore, the present classification may reflect present knowledge about their elevation distribution rather than their actual distribution.

\section{Distribution of life forms}

The pattern of life forms changed in all systematic groups with elevation, especially for vascular plants. The disappearance of geophytes and therophytes with increasing altitude has long been observed (e.g. Jenny-Lips 1948): the growth period at high altitudes is too short and too cold for these life forms. On our summits, the change of proportion between hemicryptophytes and chamaephytes (Table 4) corresponded to a steeper decrease of hemicryptophytes than chamaephytes. The latter are better adapted to rock crevices and screes, which are the main habitats where vascular plants can find the few favourable places in the very harsh conditions of the nival belt. Moreover, cushion plants (classified as chamaephytes) are particularly adapted to the alpine-nival climate (Körner 2003). Up to 2,800 m, the proportion of chamaephytes was quite stable at approximately 20-35\% (Appendix 5), which is in agreement with the $22-30 \%$ found by Theurillat et al. (2003) across $100-\mathrm{m}$ elevation sections at similar altitudes; however, this proportion increased to $50-100 \%$ above $3,000 \mathrm{~m}$. It is much higher than the $24.5 \%$ of chamaephytes observed by JennyLips (1948) for the species pool present in the nival belt of the Swiss Alps.

For bryophytes, the proportions of the different life forms in the summit sections were globally very close to previous data from Theurillat et al. (2003): there was a constant dominance of the turf form at approximately $60 \%$, and the weft form represented approximately 7\% of the species 
(Fig. 4). The increasing proportion of cushion bryophytes is probably comparable to the increase of cushion plants in the upper alpine belt, because this form has higher temperature, better wind protection, lower dehydration (Glime 2007), and perhaps also better conservation of nutrients (Körner 2003). Turf bryophytes are also efficient at maintaining moisture and are often found in crevices in alpine areas (Glime 2007). The decreasing proportion of foliaceous lichens towards the higher summits (Fig. 4) was probably due to their preference for consistently humid substrates (forest understory, gorges, moss carpets, oozes) because their shape is particularly efficient at using water from the substrate. With increasing altitude, substrates tend to dry more quickly (shallow soils, absence of plant shadow, draining effect of the slopes, intense solar radiations, wind), and the decreasing size of vascular plants eliminates protectors against dessication and reduces the large moss carpets.

The difference observed for cryptogams in quadrats compared to summit sections (Appendix 6) was probably due to the smaller diversity of microhabitats inventoried in these small plots compared to large summit sections. These small inventories reflected the dominant species (in cover) to a greater extent. For both groups, the observed shifts in dominance from turf to cushion bryophytes and from fruticose to crustaceous lichens most likely corresponded to the disappearance of vascular plant protection against wind, that dries cryptogams (evaporation) and strongly limits dew deposition. Indeed, dew is certainly an important contribution to bryophyte and lichen life on these summits in the summer, especially for fruticose lichens, which are efficient at collecting air humidity. On the higher summits, the bryophytes present were thus mainly saxicolous species (cushions for a better water retention) and terricolous lichens limited to crusts on the fine soils, as crustaceous lichens are adapted to very short available humidity (saxicolous lichens were not inventoried).

The temperature-physiography hypothesis

Altogether, these results were in line with the temperaturephysiography hypothesis (Theurillat et al. 2003). The lower, warmer summits were richer than the higher, colder summits in vascular plants, and the warmer aspects of the east and south tended to be richer than the west and north, which are colder aspects. The physiography influence was mainly observable among cryptogams: their small size means that they are more influenced by microtopography than by general topography. At the quadrat scale (microhabitat scale), they showed a very stable species richness with elevation (Fig. 1), but at the section scale, incorporating different microhabitats, they decreased in species richness with elevation. This difference between both scales is probably correlated with the decreasing diversity of microhabitats with elevation: steeper slopes and more active erosive processes result in more homogeneous conditions on the higher summits.

The difference between vascular plants and cryptogams at the quadrat scale is probably due to the better adaptation of the latter group to high altitude conditions. Indeed, Glime (2007) points out that bryophytes have a broader temperature range than vascular plants (Fig. 3), and dessication is a way to increase frost resistance. The low mean annual temperatures (or degree days) of alpine environments result in lower potential evapotranspiration and higher moisture, which are favourable conditions for these species (Grau et al. 2007). Their small sizes allow them to benefit from the warmer substrate (Körner 2003), and the decreasing vascular plant cover reduces competition (Cornelissen et al. 2001). All of these conditions result in a higher richness of cryptogam species than vascular plants on the highest summits (Grau et al. 2007). Of course, the higher richness of bryophytes compared to vascular plants was partly due to sampling differences: saxicolous bryophytes were included in samplings, whereas vascular plants require soil to develop. As soil becomes scarce with increasing elevation, plants become limited before bryophytes do. However, this argument is not valid for lichens, for which sampling was limited to terricolous species.

\section{Calcareous and siliceous summits}

The availability of two geographically close sampling regions in Graubünden, one on calcareous and one on siliceous rocks, gave us the opportunity to address the influence of substrate on species richness along the altitudinal gradient. We mainly observed higher species richness on the calcareous substrate, which was visible at the scale of the whole summits, summit sections and quadrats (Tables 1, 2; Appendix 3). However, this difference was observable at the treeline and in the lower alpine belt, but not in the nival belt (Appendix 3). Erschbamer et al. (2006) compared two GLORIA regions in the Italian Alps, one in the Southern Alps on calcareous and dolomitic rock with one in the Central Alps on siliceous rock. They observed similarly higher species richness on the calcareous substrate at the summit section scale. However, at a small scale $\left(1 \mathrm{dm}^{2}\right)$, species richness was significantly higher for species on siliceous substrate (Erschbamer et al. 2006).

Different explanations have been suggested for the higher plant richness on limestone, such a higher species pool on calcareous rocks (Zobel 1997) or an older origin of species linked to these substrates (Conti et al. 1999). More recently, Ewald (2003) suggested that this richness could be due to a bottleneck in the Pleistocene because acid soils were rarer than basic soils when refugial areas were at their minimum. Wohlgemuth and Gigon (2003) found corresponding 
patterns on the basis of different Swiss plant and vegetation databases. However, they remarked that species richness at the community scale does not only depend on the regional species pool, but also on micro-heterogeneity. In cold and rainy mountainous environments, carbonate is often dissolved in the topsoil, which results in mixtures of acidic and basic microhabitats and an increase of the species richness in communities.

\section{Conclusions}

Our results on 12 summits in the Swiss Alps support previous observations of (1) a decreasing species richness of vascular plants, bryophytes and lichens with elevation from the treeline to the nival belt; (2) the absence of broader elevation ranges for species at the highest elevations, as predicted by Rapoport's rule; and (3) a shift in the dominance of life forms with elevation. However, these general patterns differ between the three systematic groups considered. The decreasing species richness of cryptogams was observed in summit sections, but not in clusters of four $1 \times 1$-m quadrats. Similarly, cryptogams showed a dominance of species with large elevation ranges and a greater constancy of the dominant life forms along the whole altitudinal gradient in the summit sections.

Our results support the temperature-physiography hypothesis, which states that species richness along the altitudinal gradient is determined by temperature and the microhabitat diversity. Decreasing temperature with altitude limits the potential species pool of vascular plants (lower energy), and richness is further limited by a parallel decrease of microhabitats. Because bryophytes and lichens have a higher frost resistance than vascular plants, they are not influenced by the decreasing temperature at the quadrat (microhabitat) scale, but their decreasing species richness at the scale of the summit sections indicates that they are limited by the lower diversity of microhabitats in the upper alpine and nival belts.

Acknowledgments This research has been supported by the Federal Office for the Environment, the MAVA foundation, Forschungskommission SNP, the Société académique de Genève, the Département de la culture et des sports (Canton du Valais) and the Fondation Mariétan. We are really grateful to Lars Hedenäs, Eva Maier and René Schumacker for the revision of some of the collected bryophytes and to Anna Maria Fosaa and two anonymous reviewers for their useful comments on an earlier draft of the manuscript.

\section{References}

Aeschimann D, Lauber K, Moser DM, Theurillat J-P (2004) Flora alpina. Belin, Paris
Barry RG (1992) Mountain weather and climate. Routledge, London

Bates D, Maechler M (2009) Lme4: linear mixed-effects models using S4 classes (R package version 0.999375-31)

Bhattarai KR, Vetaas OR (2006) Can Rapoport's rule explain tree species richness along the Himalayan elevation gradient, Nepal? Divers Distrib 12:373-378

Braun J (1913) Die Vegetationsverhältnisse der Schneestufe in den Rätisch-Lepontischen Alpen. Ein Bild des Pflanzenlebens an seinen äussersten Grenzen. Neue Denkschriften der Schweizerischen Naturforschenden Gesellschaft 48:1-347

Bruun HH, Moen J, Virtanen R, Grytnes JA, Oksanen L, Angerbjorn A (2006) Effects of altitude and topography on species richness of vascular plants, bryophytes and lichens in alpine communities. J Veg Sci 17:37-46

Bureau de coordination du Monitoring de la Biodiversité en Suisse (2009) Etat de la biodiversité en Suisse. Etat de l'environnement $\mathrm{n}^{\circ}$ 0911. OFEV, Berne

Clerc P (2004) Les champignons lichénisés de Suisse, catalogue bibliographique complété par des données sur la distribution et l'écologie des espèces. Cryptogamica Helvetica 19:1-320

Coldea G, Pop A (2004) Floristic diversity in relation to geomorphological and climatic factors in the subalpine-alpine belt of the Rodna Mountains (The Romanian Carpathians). Pirineos 158-159:61-72

Conti E, Soltis DE, Hardig TM, Schneider J (1999) Phylogenetic relationships of the silver saxifrages (Saxifraga, sect. Ligulatae Haworth): implications for the evolution of substrate specificity, life histories, and biogeography. Mol Phylogenet Evol 13:536-555

Cornelissen JHC et al (2001) Global change and arctic ecosystems: is lichen decline a function of increases in vascular plant biomass? J Ecol 89:984-994

Cortini Pedrotti C (2001) Flora dei muschi d'Italia. Sphagnopsida, Andreaeopsida, Bryopsida (I parte). Antonio Delfino Editore, Roma

Cortini Pedrotti C (2006) Flora dei muschi d'Italia. Bryopsida (II parte). Antonio Delfino Editore, Roma

Erschbamer B, Mallaun M, Unterluggauer P (2006) Plant diversity along altitudinal gradients in the Southern and Central Alps of South Tyrol and Trentino (Italy). Gredleriana 6:47-68

Ewald J (2003) The calcareous riddle: why are there so many calciphilous species in the central European flora? Folia Geobot 38:357-366

Faraway JJ (2006) Extending the linear model with R. Chapman \& Hall/CRC, London

Gaston KJ (2000) Global patterns in biodiversity. Nature 405:220-227

Glime JM (2007) Bryophyte ecology. vol 1. Physiological ecology. Ebook sponsored by Michigan Technological University and the International Association of Bryologists. (http://www.bryoecol. mtu.edu)

Gottfried M, Pauli H, Grabherr G (1998) Prediction of vegetation patterns at the limits of plant life. A new view of the alpine-nival ecotone. Arc Alp Res 30:207-221

Grau O, Grytnes JA, Birks HJB (2007) A comparison of altitudinal species richness patterns of bryophytes with other plant groups in Nepal, Central Himalaya. J Biogeo 34:1907-1915

Grytnes JA (2003) Ecological interpretations of the mid-domain effect. Ecol Lett 6:883-888

Grytnes JA, Heegaard E, Ihlen PG (2006) Species richness of vascular plants, bryophytes, and lichens along an altitudinal gradient in western Norway. Acta Oecol 29:241-246

Grytnes JA, Heegaard E, Romdal TS (2008) Can the mass effect explain the mid-altitudinal peak in vascular plant species richness? Bas Appl Ecol 9:373-382

Huston MA (1999) Local processes and regional patterns: appropriate scales for understanding variation in the diversity of plants and animals. Oikos 86:393-401 
Jenny-Lips H (1948) Vegetation der Schweizer Alpen. Büchergilde Gutenberg, Zürich

Körner C (2000) Why are there global gradients in species richness? Mountains might hold the answer. Trends Ecol Evol 15:513-514

Körner C (2003) Alpine plant life, 2nd edn. Springer, Berlin

Körner C (2007) The use of 'altitude' in ecological research. Trends Ecol Evol 22:569-574

Lange OL (2003) Photosynthetic productivity of the epilithic lichen Lecanora muralis: long-term field monitoring of $\mathrm{CO} 2$ exchange and its physiological interpretation II. Diel and seasonal patterns of net photosynthesis and respiration. Flora 198:55-70

Lundholm JT (2009) Plant species diversity and environmental heterogeneity: spatial scale and competing hypotheses. J Veg Sci 20:377-391

McKone MJ (1993) Statistical analysis of experiments conducted at multiple sites. Oikos 67:184-186

Nimis PL, Martellos S (2008) ITALIC - the information system on italian lichens. version 4.0. In: University of Trieste, Dept. of Biology, IN4.0/1. (http://dbiodbs.univ.trieste.it/)

Nogues-Bravo D, Araujo MB, Romdal T, Rahbek C (2008) Scale effects and human impact on the elevational species richness gradients. Nature 453:216-218

Nyholm E (1986-1998) Illustrated flora of nordic mosses. Nordic Bryological Society, Copenhagen, Lund

Paton JA (1999) The liverwort flora of the British Isles. Harley Books, Cochester

Pauli H, Gottfried M, Hohenwallner D, Reiter K, Casale R, Grabherr G (2004) The GLORIA field manual. Multi-summit approach. European Commission. Office for Official Publications of the European Communities, Luxembourg

Rahbek C (1995) The elevational gradient of species richness-a uniform pattern. Ecography 18:200-205

Rahbek C (2005) The role of spatial scale and the perception of largescale species-richness patterns. Ecol Lett 8:224-239

Raunkiaer C (1934) Life-forms of plants and statistical plant geography. Clarendon Press, Oxford

Rohde K, Heap M, Heap D (1993) Rapoport's rule does not apply to marine teleosts and cannot explain latitudinal gradients in species richness. Am Nat 142:1-16
Schumacker R, Váňa J (2005) Identification keys to the liverworts and hornworts of Europe and Macaronesia (distribution and status), 2nd edn. Sorus, Poznań

Smith AJE (2004) The moss flora of Britain and Ireland. Cambridge University Press, Cambridge

Stanisci A, Pelino G, Blasi C (2005) Vascular plant diversity and climate change in the alpine belt of the central Apennines (Italy). Biodivers Conserv 14:1301-1318

Stevens GC (1992) The elevational gradient in altitudinal range, an extension of Rapoport's latitudinal rule to altitude. Am Nat 140:893-911

R Development Core Team (2009) R: A language and environment for statistical computing. In: $\mathrm{R}$ Foundation for Statistical Computing, Vienna, Austria. (http://www.R-project.org)

Theurillat J-P, Guisan A (2001) Potential impact of climate change on vegetation in the European Alps: a review. Clim Change 50:77-109; 53:529-530

Theurillat J-P, Schlüssel A, Geissler P, Guisan A, Velluti C, Wiget L (2003) Vascular plant and bryophyte diversity along elevation gradients in the Alps. In: Nagy L, Grabherr G, Körner C, Thompson DBA (eds) Alpine biodiversity in Europe, vol 167. Springer, Heidelberg, pp 185-193

Theurillat J-P, Iocchi M, Cutini M, De Marco G (2010) Vascular plant richness along an elevation gradient at Monte Velino (Central Apennines, Italy). Biogeografia 28 (in press)

Vetaas OR, Grytnes JA (2002) Distribution of vascular plant species richness and endemic richness along the Himalayan elevation gradient in Nepal. Global Ecol Biogeogr 11:291-301

Virtanen R, Crawley MJ (2010) Contrasting patterns in bryophyte and vascular plant species richness in relation to elevation, biomass and Soay sheep on St Kilda, Scotland. Plant Ecol Diver 3:77-85

Whittaker RJ (1999) Scaling, energetics and diversity. Nature 401:865-866

Wohlgemuth T, Gigon A (2003) Calcicole plant diversity in Switzerland may reflect a variety of habitat templets. Folia Geobot 38:443-452

Zobel M (1997) The relative role of species pools in determining plant species richness: an alternative explanation of species coexistence. Trends Ecol Evol 12:266-269 